\title{
RECENT SPECIATION IN THE ORCHARD ORIOLE GROUP: DIVERGENCE OF ICTERUS SPURIUS SPURIUS AND ICTERUS SPURIUS FUERTESI
}

\author{
Jason M. Baker, ${ }^{1,2}$ Esteban López-Medrano, ${ }^{1,3}$ Adolfo G. Navarro-Sigüenza, ${ }^{3}$ \\ Octavio R. Rojas-Soto, ${ }^{3}$ and Kevin E. Omland ${ }^{1,4}$ \\ ${ }^{1}$ Department of Biological Sciences, University of Maryland, Baltimore County, Baltimore, Maryland 21250, USA; \\ ${ }^{2}$ Department of Philosophy, University of Maryland, Baltimore County, Baltimore, Maryland 21250, USA; and \\ ${ }^{3}$ Museo de Zoología, Facultad de Ciencias, Universidad Nacional Autónoma de México, México, D.F. 04510, México
}

\begin{abstract}
Aвstract.-New World orioles (Icterus) include several closely related species and subspecies pairs that provide excellent opportunities for studying recent speciation. We examined a subspecies pair in the Orchard Oriole group: Orchard Oriole (I. spurius spurius), a longdistance migrant that breeds in eastern North America, and Fuertes's Oriole (I. s. fuertesi), a short-distance migrant that breeds in a restricted range in Veracruz, Mexico. We sequenced parts of the mitochondrial cytochrome- $b$ gene (925 base pairs) and control region ( 344 base pairs) from 23 Orchard Orioles and 7 Fuertes's Orioles. Subspecies are not reciprocally monophyletic. Instead, our data suggest that at least one taxon is paraphyletic or polyphyletic. We found little support for any further phylogenetic structure, including whether one subspecies might be derived from the other. However, haplotype frequency analysis suggests that there is little or no current gene flow between the taxa. The phylogenetic relationship between Orchard and Fuertes's orioles is likely a result of recent divergence and incomplete lineage sorting. That interpretation is consistent with theoretical models of speciation, which predict patterns of nonmonophyly at early stages of taxon divergence. Our findings suggest that Orchard and Fuertes's orioles are separate species and provide a case study for evaluating the importance of monophyly in defining species limits. Received 25 January 2002, accepted 22 April 2003.
\end{abstract}

Resumen.-Las calandrias del Nuevo Mundo (Icterus) incluyen un conjunto de especies cercanamente relacionadas y pares de subespecies que ofrecen oportunidades excelentes para el estudio de eventos recientes de especiación. Nosotros examinamos un par de subespecies en el grupo de los bolseros cafés: el bolsero castaño (I. spurius spurius), que es un migrante de grandes distancias que se reproduce en el este de Norteamérica, y el bolsero de Fuertes (I. $s$. fuertesi), un migrante de corta distancia que se reproduce en un área restringida en Veracruz, México. Secuenciamos partes del gen mitocondrial del citocromo- $b$ (925 pares de bases) y la región control (344 pares de bases) de 23 I. s. spurius y 7 I. s. fuertesi. Las subespecies no son recíprocamente monofiléticas. Por el contrario, los datos sugieren que al menos un taxón es parafilético o polifilético. Encontramos muy poco apoyo a cualquier otra estructura filogenética, incluyendo si alguna subespecie pudo derivarse de la otra. Sin embargo, el análisis de frecuencia de haplotipos sugiere que hay muy poco flujo genético actual entre los taxa. La relación filogenética entre los bolseros castaño y de Fuertes es más bien resultado de una divergencia reciente y una división incompleta de los linajes. Esta interpretación es consistente con los modelos teóricos de especiación reciente, los cuales predicen patrones de no-monofilia en etapas tempranas de la especiación. Nuestros resultados presentan un estudio de caso para evaluar la importancia de la monofilia en la definición de límites de especies.

THE IMPORTANCE OF monophyly for defining species limits has remained controversial in ornithology. Although some systematists insist on the reciprocal monophyly of sister species, even at the level of their component gene trees (e.g. Zink and Blackwell-Rago 2000; but see

${ }^{4}$ Address correspondence to this author. E-mail: omland@umbc.edu
Zink 2002), coalescence theory predicts patterns of paraphyly and polyphyly at early stages of speciation (Neigel and Avise 1986, Avise and Ball 1990, Hudson 1990, Avise 1994). That tension underscores the outstanding problem of establishing broadly applicable criteria to demarcate species boundaries, especially for recently diverged taxa. Here, we examined a pair of closely related New World orioles (Icterus). Rather than apply a particular species concept 
to the group, we sought to reconstruct the process of genetic divergence. That approach provides an opportunity to critically evaluate the monophyletic species criterion.

The Orchard Oriole group (Icterus spurius) presents an interesting case study of recent taxon divergence. The two subspecies in the group, Orchard Oriole (I. s. spurius, Linnaeus 1766) and Fuertes's Oriole (I. s. fuertesi, Chapman 1911), are clearly distinct in adult male plumage. Underparts, rump, uppertail coverts, and scapulars of Orchard Orioles are chestnut; whereas those of Fuertes's Orioles are tan or ochre-buff (Howell and Webb 1995). The taxa also differ widely in their breeding and wintering ranges. Orchard Orioles breed in eastern and central United States and central plains of Mexico (Scharf and Kren 1996) and winter from southwestern Mexico and the Yucatán Peninsula through Central America to northern Colombia and northwestern Venezuela (American Ornithologists' Union 1998). Hence, most Orchard Orioles migrate a long distance from temperate breeding grounds to the tropics. In contrast, Fuertes's Orioles breed from southern Tamaulipas to southern Veracruz, Mexico, and migrate, if at all, only a short distance along the southern coasts of Guerrero to Chiapas, Mexico (Jaramillo and Burke 1999; but see Scharf and Kren 1996). Importantly, breeding grounds of Orchard and Fuertes's orioles are disjunct (see Fig. 1). Finally, the taxa may differ in physical size (Chapman 1911; but see Graber and Graber 1954, Monroe 1968).

Given their differences in plumage coloration and breeding range, Orchard and Fuertes's orioles were originally described as separate species (Chapman 1911; see also Sclater 1939). Blake (1953) was the first to regard the taxa as conspecific, although Graber and Graber (1954) first provided empirical support for lumping. Graber and Graber's (1954) recommendation was based on the putative nonsignificance of observed size differences between Orchard and Fuertes's orioles and on their claim of variation in adult male plumage coloration within each taxon. Although they did not document any overlap in plumage coloration between taxa and although they suggested that the taxa likely do not interbreed, their taxonomic recommendation was accepted by Blake (1968) (see also American Ornithologists' Union 1983, 1998; Sibley and Monroe 1990). In addition,
Dickerman and Warner (1962) described a third subspecies in the group, Icterus spurius phillipsi, which they attributed to Mexico's central plateau. However, Monroe (1968) found it to be indistinguishable from nominate spurius, and it is not recognized by Monroe and Sibley (1993) or the American Ornithologists' Union (1983, 1998).

Despite the presence of several diagnosable differences between Orchard and Fuertes's orioles, a recent mitochondrial DNA study of the genus Icterus suggests that the subspecies are very closely related $(0.6 \%$ different in cytochrome- $b$ and ND2 sequences; Omland et al. 1999).

Our goals were to study the recent divergence of Orchard and Fuertes's orioles and to determine whether the taxa have evolved reciprocal monophyly. In addition, we sought to elucidate changes in plumage coloration and migration habits that occurred in the Orchard Oriole group.

\section{MetHODS}

Taxon sampling.-Muscle and skin tissues were obtained from 23 Orchard and 7 Fuertes's Orioles, collected from throughout their respective breeding ranges (Fig. 1, Appendix). For outgroup taxa, we chose the Greater Antillean Oriole (Icterus dominicensis) and the Black-cowled Oriole (I. prosthemelas; American Ornithologists' Union 2000), which are among the closest living relatives of the Orchard Oriole group (Omland et al. 1999). All samples were collected during the breeding season (15 May to 15 July).

DNA segments.-Given the close relationship between the Orchard Oriole taxa, we chose to analyze mitochondrial DNA, which evolves monophyly $4 \times$ faster than the average nuclear allele (Palumbi et al. 2001; also see Hudson and Turelli 2003) and, thus, better tracks species-level phylogenies for recently diverged taxa than any single nuclear allele (Moore 1995). The mitochondrial cytochrome- $b$ (cyt b) gene was sequenced because it has proven useful for species-level phylogenies in New World orioles (Omland et al. 1999) and other bird groups (Moore and DeFilippis 1997) and because its rate of sequence divergence has been well characterized (Fleischer et al. 1998). Domain I of the mitochondrial control region (CR) was also sequenced for its rapid mutation rate (Tarr 1995).

Laboratory procedures.-DNA was extracted from muscle and skin tissue using DNeasy Tissue Extraction Kits (Qiagen, Valencia, California). DNA samples were amplified and sequenced using the following four primers spanning 925 base pairs (bp) of 


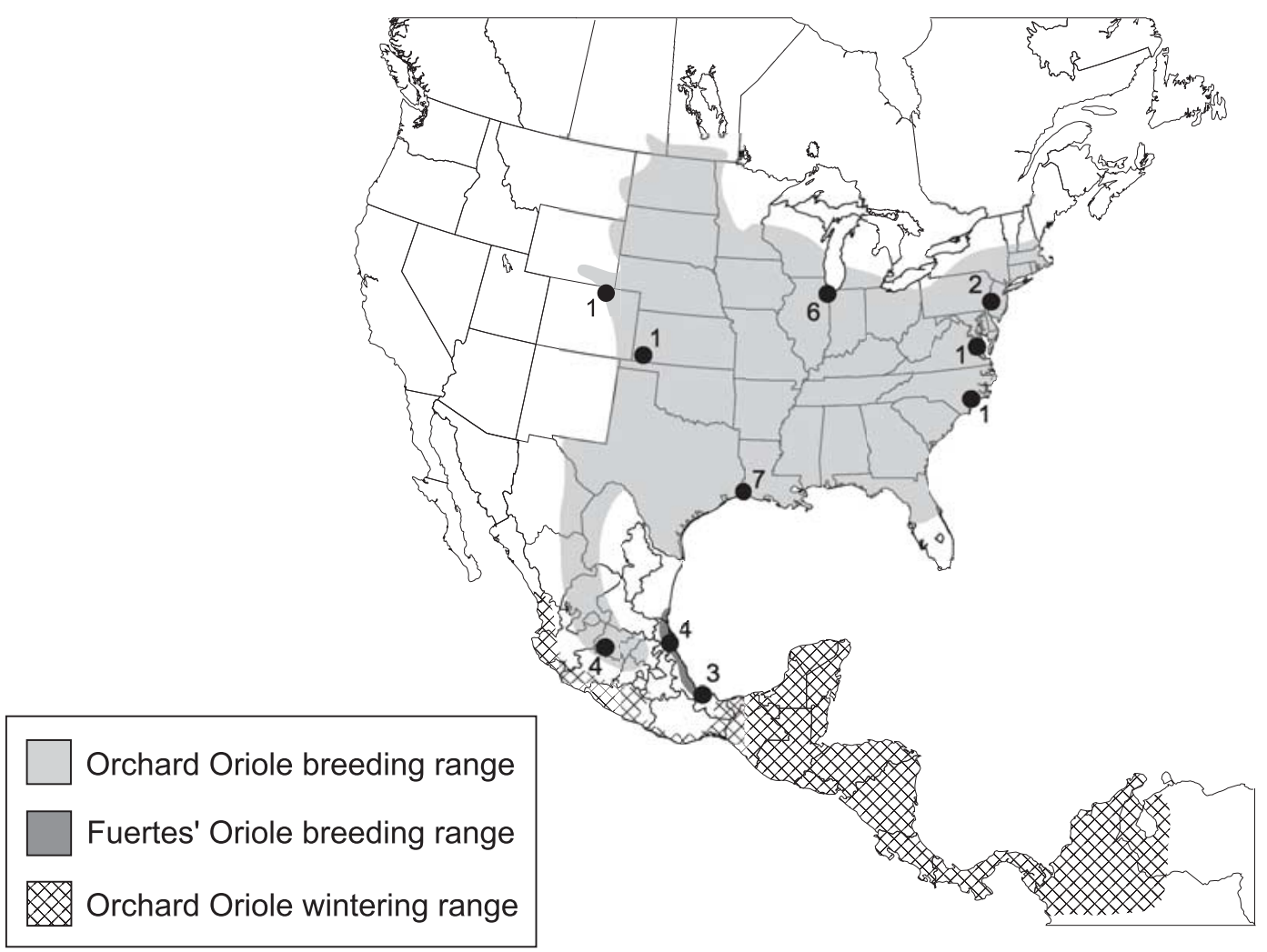

FIG. 1. Ranges of Orchard and Fuertes's orioles (adapted from Jaramillo and Burke 1999). Orchard Oriole breeding range is indicated in light gray; the wintering range, in crosshatching. Fuertes's Oriole breeding range is indicated in dark grey. Black dots indicate approximate locations of collected individuals. Sample size for each location is indicated next to each dot.

cyt b: L14990/LB1 (Kocher et al. 1989), H15424/HSH (Hackett 1996), L15350/LCBA (J. Klicka pers. comm.), and H15916/HB4 (Lanyon 1994); and the following two primers spanning 344 bp of CR: LGL2 and H417 (Tarr 1995). A typical amplification involved an initial cycle $\left(4 \mathrm{~min}\right.$ at $95^{\circ} \mathrm{C}, 1 \mathrm{~min}$ at $50^{\circ} \mathrm{C}, 45 \mathrm{~s}$ at $\left.72^{\circ} \mathrm{C}\right)$, followed by 35 cycles $\left(1 \mathrm{~min}\right.$ at $95^{\circ} \mathrm{C}, 1 \mathrm{~min}$ at $50^{\circ} \mathrm{C}, 45 \mathrm{~s}$ at $72^{\circ} \mathrm{C}$ ) and a final $10 \mathrm{~min}$ extension at $72^{\circ} \mathrm{C}$. Polymerase chain reaction (PCR) products were cleaned using QIAquick PCR Purification Kits (Qiagen). Cytochrome- $b$ and CR segments were sequenced in both directions using the above primers and Big Dye Chemistry (version 2, Applied Biosystems, Inc. [ABI], Foster, California) following ABI protocols. Cyclesequenced products were cleaned using an ethanol precipitation protocol recommended by $\mathrm{ABI}$ and sequenced on an ABI 3100 automated sequencer. All 30 individuals were sequenced for $\mathrm{CR}$, and a subset of 11 Orchard and all Fuertes's orioles for cyt $b$. All sequences were deposited into GenBank under accession numbers AY211195-AY211215, AY212245 (cyt $b$ ) and AY211216-AY211247 (CR). Cytochrome- $b$ sequence for one Black-cowled Oriole was obtained from a previous study (Omland et al. 1999, GenBank accession no. AF099289).

Genetic analyses.-DNA sequences were aligned using SEQUENCHER (version 4.1; Gene Codes Corporation, Ann Arbor, Michigan). Uncorrected pairwise distance values were computed for both cyt- $b$ and CR segments in PAUP* (version 4.0b8, Swofford 1999). Cytochrome- $b$ and CR data sets were analyzed separately using maximum parsimony and the combined data set using maximum parsimony and maximum likelihood in PAUP*. A partition homogeneity test was performed in PAUP* to determine whether the cyt- $b$ and CR data sets were significantly incongruent. Maximum parsimony analyses were conducted using the heuristic search algorithm with 1,000 random additions. There are no insertions or deletions in the data sets, and all characters were equally weighted. By using hierarchical likelihood-ratio tests in MODELTEST (version 3.04; Posada and Crandall 1998), it was determined that the HKY $85+\Gamma$ model (Hasegawa et al. 1985, Yang 1994) best fit our data. 
We used the heuristic search algorithm with 1,000 random additions to construct the maximum-likelihood tree, successively estimating tree parameters until a stable topology was found.

Control region haplotype data were also analyzed using hierarchical analyses of molecular variance (AMOVA) (Excoffier et al. 1992) to test for significant population structure. Pairwise fixation indices $\left(F_{\mathrm{ST}}\right)$ were calculated for populations at several hierarchical levels using ARLEQUIN (version 2.0; Schneider et al. 2000). Those $F_{\mathrm{ST}}$ values indicate how molecular variation is apportioned among hierarchical levels and provide an upper bound on the relative amount of gene flow that occurs among individuals at each level. For the purpose of those analyses, Orchard Oriole was divided into a Mexican population (corresponding to the putative range of Icterus spurius phillipsi) and the following US populations: eastern (Pennsylvania, Virginia, North Carolina), central (Illinois), southern (Louisiana), and western (Colorado, Kansas). We divided Fuertes's Oriole into northern (northern Veracruz) and southern (southern Veracruz) populations (see Fig. 1).

\section{RESULTS}

Sequence data.-Of the 925 bp of cyt- $b$ sequence, $10(1.08 \%)$ sites were variable and $3(0.32 \%)$ were parsimony informative. Of the $344 \mathrm{bp}$ of CR sequence, nine $(2.62 \%)$ sites were variable and three $(0.87 \%)$ were parsimony informative. The minimum, maximum, and average genetic distances within and between Orchard and Fuertes's orioles are shown in Table 1 . The average genetic distance between the subspecies for both DNA segments is slightly greater than that within taxa. For cyt $b$, the average genetic distance between the taxa is $0.20 \%$, whereas the average distances within Orchard and Fuertes's oriole are 0.19 and $0.12 \%$, respectively.

Phylogenetic analyses.-The equally weighted maximum-parsimony search on the CR data set produced one most parsimonious topology (presented as an unrooted haplotype network in Fig. 2). Although that analysis showed that the haplotypes of the two subspecies are intermixed, it also showed different haplotype frequencies between the taxa (see below). We also constructed rooted phylograms for cyt- $b$ and CR data sets separately, again using the equally weighted maximum parsimony search (e.g. Fig. 3). The partition homogeneity test in PAUP* detected no significant incongruence between cyt- $b$ and $C R$ data sets $(P=0.092)$. The only obvious incongruence was the placement
TABLE 1. Genetic distances within and between Orchard Oriole taxa (uncorrected percentages for cytochrome- $b$ and control-region segments).

\begin{tabular}{lcc}
\hline \hline \multicolumn{2}{c}{ Cytochrome $b$} & Control region \\
\hline Between subspecies & & \\
Range & $(0.00-0.43)$ & $(0.00-1.16)$ \\
Mean & 0.20 & 0.77 \\
Within Orchard Oriole & \\
Range & $(0.00-0.43)$ & $(0.00-0.87)$ \\
Mean & 0.19 & 0.30 \\
Within Fuertes's Oriole & \\
Range & $(0.00-0.22)$ & $(0.00-0.87)$ \\
Mean & 0.12 & 0.27 \\
\hline
\end{tabular}

of IL-6, whether within the main haplotype of Orchard Oriole (cyt b, Fig. 2) or the main haplotype of Fuertes's Oriole (CR, Fig. 3); however, a single homoplasy in cyt $b$ could account for that incongruence. We combined the cyt- $b$ and CR data sets for maximum-parsimony and maximum-likelihood analyses. The four shortest trees generated by the equally weighted maximum-parsimony search on the combined data set was 92 steps long and showed both taxa polyphyletic (sensu Avise 1994). When constrained to recover only trees that showed Fuertes's or Orchard oriole monophyletic, the equally weighted maximum-parsimony search generated eight shortest trees of 93 steps. A comparison of the two hypotheses using a twotailed Wilcoxon signed-ranks test (Templeton 1983 ) in PAUP* could not rule out the monophyly of either taxon $(P>0.5)$, but could rule out the reciprocal monophyly of both taxa $(P<$ $0.0001)$. The maximum-likelihood search on the combined data set found a single tree $(-\operatorname{lnl}=$ 2119.52) with the following parameter values: transition-transversion ratio $(\mathrm{ti} / \mathrm{tv})=7.2539, \Gamma$ distribution shape $(\alpha)=0.1574$, and empirical base frequencies (Fig. 4). That tree was similar to the trees generated by the unconstrained maximum-parsimony search on the combined data set.

Our phylogenetic analyses of both separate and combined data sets revealed intermixing of the subspecies' haplotypes and strongly suggested that the taxa are not reciprocally monophyletic. We found little support for any further phylogenetic structure, including whether one taxon might be derived from the other.

Analysis of population genetics.-Analysis of geographic structure using ARLEQUIN revealed significant genetic differentiation 


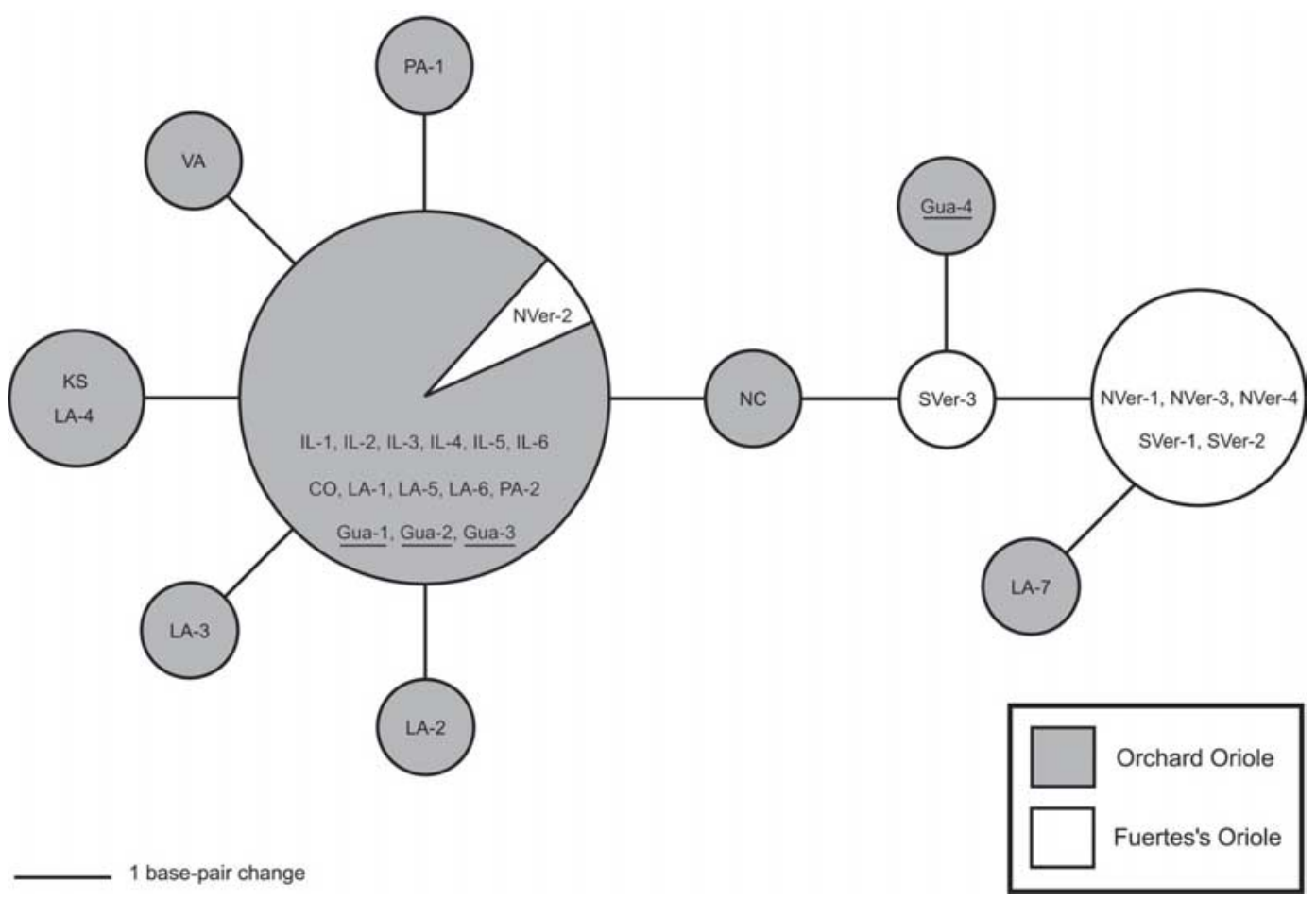

FIG. 2. Unrooted haplotype network based on control-region sequences. Network was obtained using the equally weighted maximum-parsimony search in PAUP*, which produced one most parsimonious network. Branch lengths are uncorrected and correspond to a single base-pair change. Relative haplotype frequencies are indicated by area of circles. Locations are abbreviated as in the appendix. Orchard Orioles collected from Mexico (the putative breeding range of I. s. phillipsi) are underlined. Note the blatant differences in haplotype frequencies between Orchard and Fuertes's orioles.

between Orchard and Fuertes's orioles $\left(F_{\mathrm{ST}}=\right.$ $0.608, P<0.00001)$, which strongly suggests there is little or no current gene flow between subspecies. Using ARLEQUIN, we estimated that 0.3 migrants per generation could account for our findings. In contrast, there is no evidence of genetic differentiation within either subspecies $(P>0.75)$ (See Table 2).

\section{DisCUSSION}

Lack of reciprocal monophyly.-Our findings based on cyt- $b$ and CR sequence data show that the haplotypes of Orchard and Fuertes's Orioles are intermixed and that the taxa are not reciprocally monophyletic. Those patterns could result from recent divergence and incomplete lineage sorting (see Moran and Kornfield 1993, Seutin et al. 1995). Coalescence theory predicts patterns of nonmonophyly at early stages of speciation (Neigel and Avise 1986, Avise and Ball 1990,
Hudson 1990, Avise 1994), which is consistent with our findings. Lineage sorting at neutral sites is a stochastic process, and the probability that reciprocal monophyly will evolve in a pair of populations increases with smaller effective population size and longer time since interruption of gene flow (Hudson 1990). Any pair of populations will eventually become reciprocally monophyletic (or exclusive) after gene flow has ceased, because ancestral polymorphism is sorted and unique mutations are acquired (Avise 1994, Baum and Shaw 1995, Shaw 1998). For example, after $0.1 \mathrm{~N}$ generations since the interruption of gene flow (where $N$ is the effective population size), $13 \%$ of population pairs will be reciprocally monophyletic. After $N$ and $4 \mathrm{~N}$ generations, 35 and $83 \%$ will show that pattern, respectively (table 2.2 in Harrison 1998). Thus, if Orchard and Fuertes's orioles diverged recently, the probability that the taxa would be reciprocally monophyletic is quite low, even if 


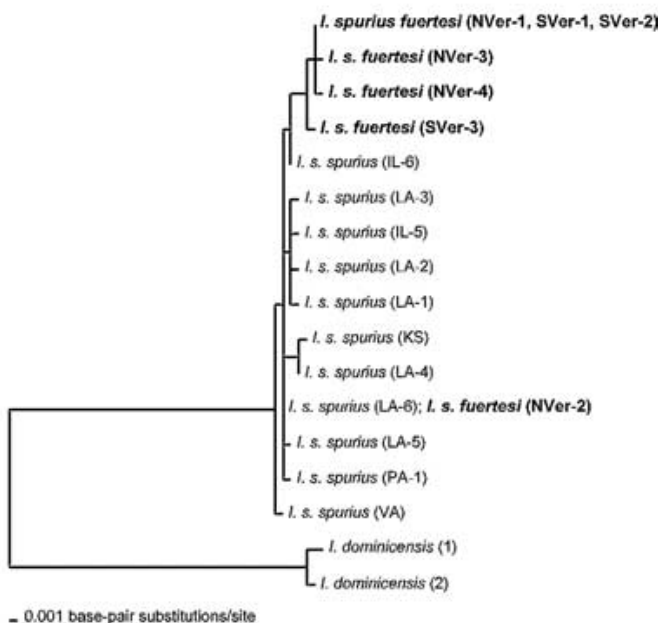

FIG. 3. Phylogram based on cytochrome- $b$ sequences. Tree was obtained using the equally weighted MP search in PAUP*, which produced one most parsimonious tree. Branch lengths are uncorrected. Locations are abbreviated as in the appendix. Fuertes's Orioles are highlighted in bold. Note that the haplotypes of both subspecies are intermixed.

they do not exchange any genes. Incomplete lineage sorting, therefore, is sufficient to account for our data.

Alternatively, our findings may be accounted for by hybridization between subspecies after they diverged (Avise et al. 1990, Avise 1994; see also Holder et al. 2001, Weckstein et al. 2001). Although no hybrids have been observed, there has not been sufficient field work to completely reject that hypothesis. Nevertheless, even if there is some gene flow between subspecies, it must be rare given the haplotype frequency differences between the taxa (see Table 2). Another conceivable partial explanation for our data is homoplasy. Unconstrained phylogenies based on combined cyt- $b$ and CR data sets, which show the polyphyly of both Orchard and Fuertes's orioles, are only one step shorter than

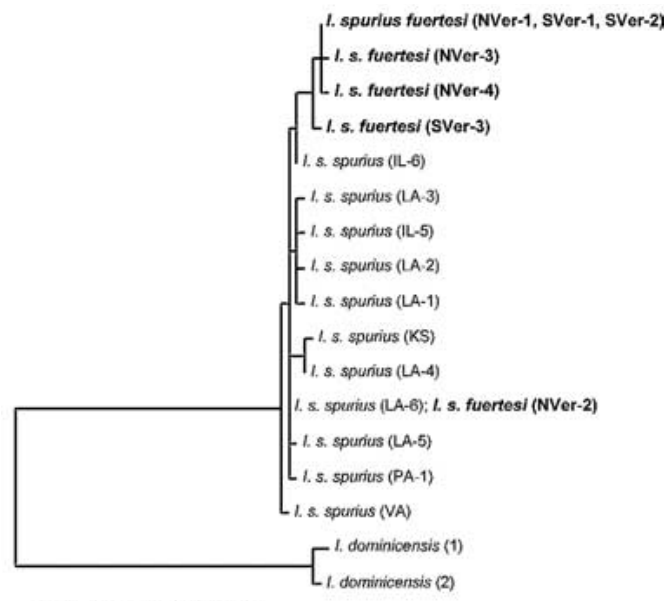

-0.001 base-pair substitutions/site

FIG. 4. Phylogram based on combined cytochrome$b$ and control-region sequences. Tree was obtained using the maximum-liklihood search in PAUP*. We used the HKY85 $+\Gamma$ model to construct the tree $(-\operatorname{lnl}=$ 2,119.52), which had the following parameter values: $\mathrm{ti} / \mathrm{tv}=7.2539, \alpha=0.1574$, and empirical base frequencies. Locations are abbreviated as in the appendix. Fuertes's Orioles are highlighted in bold.

phylogenies constrained to show the monophyly of either taxon (but not both). Thus, a reversal at a single nucleotide site would have rendered one of the subspecies monophyletic and the other, paraphyletic.

Haplotype sharing.-Despite a low sample size for Fuertes's Oriole $(n=7)$, we found clear evidence of haplotype sharing and nonmonophyly between the Orchard Oriole subspecies. Thus, however representative our samples are for the taxon, we know that at least some Fuertes's Orioles share haplotypes with some Orchard Orioles. Furthermore, additional mitochondrial sequence data (e.g. from different gene regions) should reflect the same qualitative pattern (i.e. polyphyly), because mitochondria are inherited as a single linked locus. Unfortunately, nuclear

TABLE 2. Results of AMOVA (Excoffier et al. 1992). Fixation indices $\left(F_{\mathrm{ST}}\right)$ for Orchard Oriole and Fuertes's Oriole based on control-region sequence data. Note the significant differentiation between subspecies.

\begin{tabular}{lcccc}
\hline \hline Source of variation & $\begin{array}{c}\text { Variance } \\
\text { components }\end{array}$ & $\begin{array}{c}\text { Percent } \\
\text { variation }\end{array}$ & $F_{\mathrm{ST}}$ & $P$ value \\
\hline $\begin{array}{c}\text { Between subspecies } \\
\begin{array}{c}\text { Among populations/ } \\
\text { within subspecies }\end{array}\end{array}$ & 0.78589 & 60.75 & 0.608 & $<0.000001$ \\
$\begin{array}{c}\text { Among individuals/ } \\
\text { within populations }\end{array}$ & -0.02338 & -1.81 & -0.046 & 0.75269 \\
\hline
\end{tabular}


genes are much less likely to show fixed differences between species, so even rapidly evolving regions such as introns are extremely likely to show complete sharing of haplotypes at such low levels of divergence (Moore 1995, Palumbi et al. 2001). The patterns we found, therefore, likely reflect some part of the taxa's "true" evolutionary history.

Haplotype frequencies.-We found strong evidence from CR haplotype frequency data that Orchard and Fuertes's orioles constitute distinct populations that exchange few if any genes with each other (Table 2). Similar differences in haplotype frequencies have been found in other pairs of recently diverged taxa (e.g. Kahn et al. 1999; but see Lovette and Bermingham 2001). Our data further show that Orchard Oriole is a single panmictic population, which supports the lumping of the Mexican population (sometimes referred to as Icterus spurius phillipsi) with US populations. That finding suggests that there is extensive gene flow across the Orchard Oriole breeding range or that the taxon underwent a recent range expansion, perhaps following glacial retreat (see below).

Rapid changes in plumage and migration habits.-The maximum distance in cyt- $b$ sequence in the Orchard Oriole group is $0.43 \%$. Assuming a divergence rate in mitochondrial coding sequence of $2 \% \mathrm{Ma}^{-1}$ (Fleischer et al. 1998), we estimate that the group began to diverge from a common ancestor roughly 200,000 years ago (see also Barraclough and Nee 2001, Nichols 2001). That estimate places the subsequent origin of the two subspecies in the recent Pleistocene (cf. Klicka and Zink 1997, 1999). Because the taxa are not reciprocally monophyletic, we cannot date the actual speciation event. Rather, we estimate the date when the mitochondrial DNA lineages within the entire complex began to diverge. That provides an upper-bound estimate on when speciation could have first occurred and avoids the need to correct for ancestral polymorphism.

The tiny genetic distance between Orchard and Fuertes's orioles further suggests that those taxa diverged from each other quite recently. The mean genetic distance in cyt- $b$ sequence between the subspecies $(0.20 \%)$ is less than that between any subspecies pair Avise and Walker (1998) reported (see also table 2 in Helbig et al. 1995). Thus, changes in plumage coloration and migration habits must have evolved within a relatively short time span. Plumage coloration is known to be important in mate choice in Orchard Orioles (Enstrom 1993), so sexual selection could have driven that rapid plumage change. Previous studies have documented rapid evolution in plumage characters across the New World orioles (e.g. Omland and Lanyon 2000) and other bird groups (e.g. Zink 1996, Kusmierski et al. 1997, Burns 1998).

Monophyly and species limits.-Biologists and philosophers have long debated the definition of species taxa (reviewed in Hull 1988, 2001; Mayden 1997). Among the many species concepts currently in use, phylogenetic species concepts in their various forms (Cracraft 1983, Donoghue 1985, Mishler and Brandon 1987) have recently attracted much attention in ornithology (Zink and McKitrick 1995, Cracraft 1997). According to those accounts, species are historical entities that are defined in terms of their component genic or population-level lineages. The monophyly of those component lineages is often used as a criterion to define species limits (e.g. Donoghue 1985, Mishler and Brandon 1987, McKitrick and Zink 1988, Baum and Shaw 1995; but see Horvath 1997). Yet theoretical models of speciation, including coalescence theory (Neigel and Avise 1986, Avise and Ball 1990, Avise 1994), predict patterns of nonmonophyly at early stages of speciation (see also Patton and Smith 1994, Crisp and Chandler 1996, Harrison 1998). Recently diverged species will not demonstrate reciprocal monophyly for some time after they have stopped exchanging genes (Hudson 1990). Moreover, evolution of reciprocal monophyly does not appear to mark the boundary of any evolutionarily significant event. Rather, it is a pattern caused by the stochastic process of gene sorting, which may or may not be correlated with changes in behavioral, ecological, or morphological characters. Thus, phylogenetic species concepts that require monophyly may inappropriately demarcate species limits, especially for closely related taxa. Reciprocal monophyly, like each proposed species criterion, is perhaps best viewed as an imperfect diagnostic tool for determining species status (O'Hara 1994; de Queiroz 1998, 1999). For both theoretical (Kitcher 1984, 1989; Hull 1997; Dupré 1999) and empirical (de Queiroz 1998) reasons, the search for a single, defining species criterion may be a search fundamentally misguided. 
Pursuant to that view, we recommend a reconsideration of the taxonomy of the Orchard Oriole group. Orchard and Fuertes's orioles are diagnosably distinct (sensu Cracraft 1983) in their breeding ranges and adult male plumage coloration, and the taxa likely exchange few if any genes with each other. Despite some variation, there is no overlap in plumage coloration between the subspecies, and variation within each taxon is less than that between taxa (J. M. Baker pers. obs; see also Sharf and Kren 1996). In our view, those indications of evolutionary divergence are significant. The relationship between Orchard and Fuertes's orioles, therefore, may be better captured at the generic level. In contrast, we found no molecular support for the recognition of the Mexican population (or Icterus spurius phillipsi), as distinct from the US populations, in the Orchard Oriole. That finding supports their current lumping (Monroe and Sibley 1993, American Ornithologists' Union 1998).

Summary.-The Orchard Oriole group provides an excellent example of recent taxon divergence. Our data suggest that the subspecies are polyphyletic, despite the probable lack of gene flow between the taxa and the presence of diagnosable differences in adult male plumage coloration, breeding range, and migration habits. Those patterns are indicative of recent speciation. In our view, Orchard and Fuertes's orioles are evolutionarily distinct taxa and should be treated as separate species. Our findings may also have conservation implications for Fuertes's Oriole, whose restricted range makes it potentially vulnerable to wide-scale habitat changes.

\section{ACKNOWLEDGMENTS}

We thank C. R. Feldman for technical assistance and helpful discussions. R. C. Fleischer, R. Greenberg, and S. M. Lanyon provided logistical and financial support during tissue collection. S. López de Aquino and other students and staff at the Museo de Zoología, Universidad Nacional Autónoma de México (UNAM) provided assistance with collecting Fuertes's Oriole specimens. The Consejo Nacional de Ciencia y Technología provided financial support for the frozen tissue collection at the Museo de Zoología, UNAM. We thank the following institutions for tissue loans: Academy of Natural Sciences, Philadelphia; Field Museum of Natural History; J. F. Bell Museum of Natural History, University of Minnesota; Louisiana State University Museum of Zoology; Museo de
Zoología, UNAM; Museum of Vertebrate Zoology, University of California, Berkeley; North Carolina State Museum; and University of Kansas Natural History Museum. Members of the Omland Lab and P. G. Sokolove provided helpful suggestions on earlier versions of the manuscript, and J. J. Pfeifer provided helpful discussions and encouragement. K. E. Omland was supported by a National Science Foundation (NSF) Starter Grant (DEB-0004400). J.M.B. was supported by an NSF Research Experience for Undergraduates Supplement. The late N. K. Klein provided outgroup tissue from Icterus dominicensis specimens. We honor her memory and are grateful for her generous support of our oriole work and avian systematics in general.

\section{Literature Cited}

American Ornithologists' Union. 1983. Check-list of North American Birds, 6th ed. American Ornithologists' Union, Washington, D.C.

American Ornithologists' Union. 1998. Check-list of North American Birds, 7th ed. American Ornithologists' Union, Washington, D.C.

AMERICAN ORNithologists' Union. 2000. FortySecond Supplement to the Check-list of North American Birds. Auk 117:847-858.

Avise, J. C. 1994. Molecular Markers, Natural History, and Evolution. Chapman and Hall, New York.

Avise, J. C., C. D. Ankney, And W. S. Nelson. 1990. Mitochondrial gene trees and the evolutionary relationships between Mallard and Black Ducks. Evolution 44:1109-1119.

Avise, J. C., And R. M. Ball, JR. 1990. Principles of genealogical concordance in species concepts and biological taxonomy. Pages 45-67 in Oxford Surveys in Evolutionary Biology, no. 7 (D. J. Futuyma and J. Antonovics, Eds.). Oxford University Press, New York.

Avise, J. C., And D. Walker. 1998. Pleistocene phylogeographic effects on avian populations and the speciation process. Proceedings of the Royal Society of London, Series B 265:457-463.

Barraclough, T. G., and S. Nee. 2001. Phylogenetics and speciation. Trends in Ecology and Evolution 16:391-399.

Baum, D. A., AND K. L. Shaw. 1995. Genealogical perspectives on the species problem. Pages 289-303 in Monographs in Systematic Botany from the Missouri Botanical Garden, no. 53 (P. C. Hoch and A. G. Stephenson, Eds.). Missouri Botanical Garden, St. Louis.

Blake, E. R. 1953. Birds of Mexico. University of Chicago Press, Chicago.

BlaKe, E. R. 1968. Family Icteridae. Pages 138-202 in Check-list of Birds of the World, vol. 14 (R. A. Paynter, Jr., Ed.). Museum of Comparative Zoology, Cambridge, Massachusetts. 
BuRns, K. J. 1998. Molecular phylogenetics of the genus Piranga: Implications for biogeography and the evolution of morphology and behavior. Auk 115:621-634.

Chapman, F. M. 1911. Description of a new oriole (Icterus fuertesi) from Mexico. Auk 28:1-4.

Cracraft, J. 1983. Species concepts and speciation analysis. Current Ornithology 1:159-187.

CRACRAFT, J. 1997. Species concepts in systematics and conservation biology: An ornithological viewpoint. Pages 325-339 in Species: The Units of Biodiversity (M. F. Claridge, H. A. Dawah, and M. R. Wilson, Eds.). Chapman and Hall, London.

Crisp, M. D., And G. T. Chandler. 1996. Paraphyletic species. Telopea 6:813-844.

DE QUEIROZ, K. 1998. The general lineage concept of species, species criteria, and the process of speciation: A conceptual unification and terminological recommendations. Pages 57-75 in Endless Forms: Species and Speciation (D. J. Howard and S. H. Berlocher, Eds.). Oxford University Press, New York.

DE QueIroz, K. 1999. The general lineage concept of species and the defining properties of the species category. Pages 49-89 in Species: New Interdisciplinary Essays (R. A. Wilson, Ed.). Bradford Books/Massachusetts Institute of Technology Press, Cambridge.

Dickerman, R. W., AND D. W. WARNER. 1962. A new Orchard Oriole from Mexico. Condor 64: 311-314.

Donoghue, M. J. 1985. A critique of the biological species concept and recommendations for a phylogenetic alternative. Bryologist 88:172-181.

Dupré, J. 1999. On the impossibility of a monistic account of species. Pages 3-22 in Species: New Interdisciplinary Essays (R. A. Wilson, Ed.). Bradford Books/Massachusetts Institute of Technology Press, Cambridge.

Enstrom, D. A. 1993. Female choice for age-specific plumage in the Orchard Oriole: Implications for delayed plumage maturation. Animal Behaviour 45:435-442.

Excoffier, L., P. E. Smouse, AND J. M. Quattro. 1992. Analysis of molecular variance inferred from metric distances among DNA haplotypes: Application to human mitochondrial DNA restriction region. Genetics 131:479-491.

Fleischer, R. C., C. E. McIntosh, and C. L. Tarr. 1998. Evolution on a volcanic conveyor belt: Using phylogeographic reconstructions and $\mathrm{K}$-Ar-based ages of the Hawaiian Islands to estimate molecular evolutionary rates. Molecular Ecology 7:533-545.

Graber, R. R., and J. W. Graber. 1954. Comparative notes on Fuertes's and Orchard orioles. Condor 56:274-282.
HacketT, S. J. 1996. Molecular phylogenetics and biogeography of tanagers in the genus Ramphocelus (Aves). Molecular Phylogenetics and Evolution 5:368-382.

HARRISON, R. G. 1998. Linking evolutionary pattern and process: The relevance of species concepts for the study of speciation. Pages 19-31 in Endless Forms: Species and Speciation (D. J. Howard and S. H. Berlocher, Eds.). Oxford University Press, New York.

Hasegawa, M., K. Kishino, and T. Yano. 1985. Dating of the human-ape splitting by a molecular clock of mitochondrial DNA. Journal of Molecular Evolution 21:160-174.

Helbig, A. J., I. Seibold, J. Martens, and M. Wink. 1995. Genetic differentiation and phylogenetic relationships of Bonelli's Warbler Phylloscopus bonelli and Green Warbler P. nitidus. Journal of Avian Biology 26:139-153.

Holder, M. T., J. A. Anderson, AND A. K. Holloway. 2001. Difficulties in detecting hybridization. Systematic Biology 50:978-982.

Horvath, C. D. 1997. Phylogenetic species concept: Pluralism, monism, and history. Biology and Philosophy 12:225-232.

Howell, S. N. G., AND S. Webb. 1995. A Guide to the Birds of Mexico and Northern Central America. Oxford University Press, Oxford.

HudSON, R. R. 1990. Gene genealogies and the coalescent process. Pages 1-44 in Oxford Surveys in Evolutionary Biology, no. 7 (D. J. Futuyma and J. Antonovics, Eds.). Oxford University Press, New York.

Hudson, R. R., AND M. Turelli. 2003. Stochasticity overrules the "three-times rule": Genetic drift, genetic draft, and coalescence times for nuclear loci versus mitochondrial DNA. Evolution 57:182-190.

Hull, D. L. 1988. Science as a Process: An Evolutionary Account of the Social and Conceptual Development of Science. University of Chicago Press, Chicago.

Hull, D. L. 1997. The ideal species concept: And why we can't get it. Pages 357-380 in Species: The Units of Biodiversity (M. F. Claridge, H. A. Dawah, and M. R. Wilson, Eds.). Chapman and Hall, London.

Hull, D. L. 2001. The role of theories in biological systematics. Studies in History and Philosophy of Science, part C 32:221-238.

Jaramillo, A., and P. BurKe. 1999. New World Blackbirds: The Icterids. Princeton University Press, Princeton, New Jersey.

Kahn, N. W., C. E. Braun, J. R. Young, S. Wood, D. R. Mata, And T. W. Quinn. 1999. Molecular analysis of genetic variation among large- and small-bodied Sage Grouse using mitochondrial control-region sequences. Auk 116:819-824. 
Kitcher, P. 1984. Species. Philosophy of Science 51: 303-333.

Kitcher, P. 1989. Some puzzles about species. Pages 183-208 in What the Philosophy of Biology Is: Essays Dedicated to David Hull (M. Ruse, Ed.). Kluwer Academic, Dordrecht, The Netherlands.

KlickA, J., AND R. M. Zink. 1997. The importance of recent ice ages in speciation: A failed paradigm. Science 277:1666-1669.

Klicka, J., AND R. M. ZINK. 1999. Pleistocene effects on North American songbird evolution. Proceedings of the Royal Society of London, Series B 366:695-700.

Kocher, T. D., W. K. Thomas, A. Meyer, S. V. Edwards, S. Paabo, F. X. Villablanca, and A. C. WiLSON. 1989. Dynamics of mitochondrial DNA evolution in mammals: Amplification and sequencing with conserved primers. Proceedings of the National Academy of Sciences USA 86:6196-6200.

Kusmierski, R., G. Borgia, A. Uy, and R. H. Crozier. 1997. Labile evolution of display traits in bowerbirds indicates reduced effects of phylogenetic constraint. Proceedings of the Royal Society of London, Series B 264:307-313.

LANYON, S. M. 1994. Polyphyly of the blackbird genus Agelaius and the importance of assumptions of monophyly in comparative studies. Evolution 48:679-693.

Linnaeus, C. 1766. Oriolus spurius. Page 162 in Systema Naturae ..., 12th ed., vol. 1. L. Salvii, Stockholm, Sweden.

LOvetTe, I. J., AND E. Bermingham. 2001. Mitochondrial perspective on the phylogenetic relationship of the Parula wood-warblers. Auk 118:211-215.

MAYDEN, R. L. 1997. A hierarchy of species concepts: The denouement in the saga of the species problem. Pages 381-424 in Species: The Units of Biodiversity (M. F. Claridge, H. A. Dawah, and M. R. Wilson, Eds.). Chapman and Hall, London.

McKitrick, M. C., AND R. M. Zink. 1988. Species concepts in ornithology. Condor 90:1-14.

Mishler, B. D., AND R. N. BRANDON. 1987. Individuality, pluralism, and the phylogenetic species concept. Biology and Philosophy 2: 397-414.

Monroe, B. L., JR. 1968. A Distributional Survey of the Birds of Honduras. Ornithological Monographs, no. 7.

Monroe, B. L., JR., And C. G. Sibley. 1993. A World Checklist of Birds. Yale University Press, New Haven, Connecticut.

Moore, W. S. 1995. Inferring phylogenies from mtDNA variation: Mitochondrial-gene trees versus nuclear-gene trees. Evolution 49:718-726.
Moore, W. S., and V. R. DeFilippis. 1997. The window of taxonomic resolution for phylogenies based on mitochondrial cytochrome $b$. Pages 84-120 in Avian Molecular Evolution and Systematics (D. P. Mindell, Ed.). Academic Press, San Diego, California.

Moran, P., AND I. Kornfield. 1993. Retention of an ancestral polymorphism in the mbuna species flock (Teleostei: Cichlidae) of Lake Malawi. Molecular Biology and Evolution 10: 1015-1029.

Neigel, J. E., And J. C. Avise. 1986. Phylogenetic relationships of mitochondrial DNA under various demographic models of speciation. Pages 515-534 in Evolutionary Processes and Theory (S. Karlin and E. Nevo, Eds.). Academic Press, Orlando, Florida.

Nichols, R. 2001. Gene trees and species trees are not the same. Trends in Ecology and Evolution 16:358-364.

O'Hara, R. J. 1994. Evolutionary history and the species problem. American Zoologist 34:12-22.

OMland, K. E., AND S. M. LANYON. 2000. Reconstructing plumage evolution in orioles (Icterus): Repeated convergence and reversal in patterns. Evolution 54:2119-2133.

Omland, K. E., S. M. Lanyon, and S. J. Fritz. 1999. A molecular phylogeny of the New World orioles (Icterus): The importance of dense taxon sampling. Molecular Phylogenetics and Evolution 12:224-239.

Palumbi, S. R., F. Cipriano, and M. P. Hare. 2001. Predicting nuclear gene coalescence from mitochondrial data: The three-times rule. Evolution 55:859-868.

Patton, J. L., And M. F. Smith. 1994. Paraphyly, polyphyly, and the nature of species boundaries in pocket gophers (genus Thomomys). Systematic Biology 43:11-26.

Posada, D., AND K. A. CRandall. 1998. MODELTEST: Testing the model of DNA substitution. Bioinformatics 14:817-818.

Scharf, W. C., AND J. Kren. 1996. Orchard Oriole (Icterus spurius). In The Birds of North America, no. 255 (A. Poole and F. Gill, Eds.). Academy of Natural Sciences, Philadelphia, and American Ornithologists' Union, Washington, D.C.

Schneider, S., D. Roessli, and L. Excoffier. 2000. ARLEQUIN: A Software Package for Population Genetics, version 2.0. University of Geneva, Geneva, Switzerland.

SClater, W. L. 1939. A note on some American orioles of the family Icteridae. Ibis 1939:140-145.

Seutin, G., L. M. Ratcliffe, and P. T. Boag. 1995. Mitochondrial DNA homogeneity in the phenotypically diverse redpoll finch complex (Aves: Carduelinae: Carduelis flammea-hornemanni). Evolution 49:962-973. 
SHaw, K. L. 1998. Species and the diversity of natural groups. Pages 44-56 in Endless Forms: Species and Speciation (D. J. Howard and S. H. Berlocher, Eds.). Oxford University Press, New York.

Sibley, C. G., and B. L. Monroe, JR. 1990. Distribution and Taxonomy of Birds of the World. Yale University Press, New Haven, Connecticut.

SwoFford, D. L. 1999. PAUP*: Phylogenetic Analysis Using Parsimony (*and Other Methods), version 4.0b8. Sinauer Associates, Sunderland, Massachusetts.

TARR, C. L. 1995. Primers for amplification and determination of mitochondrial control-region sequences in oscine passerines. Molecular Ecology 4:527-529.

Templeton, A. R. 1983. Phylogenetic inference from restriction endonuclease cleavage site maps with particular reference to the evolution of humans and the apes. Evolution 37:221-244.

Weckstein, J. D., R. M. ZinK, R. C. Blackwell-Rago, And D. A. Nelson. 2001. Anomalous variation in mitochondrial genomes of White-crowned (Zonotrichia leucophrys) and Golden-crowned (Z. atricapilla) sparrows: Pseudogenes, hybridization, or incomplete lineage sorting? Auk 118:231-236.

YANG, Z. 1994. Maximum likelihood phylogenetic estimation from DNA sequences with variable rates over sites: Approximate methods. Journal of Molecular Evolution 39:306-314.

ZINK, R. M. 1996. Species concepts, speciation, and sexual selection. Journal of Avian Biology 27: $1-6$.

ZINK, R. M. 2002. A new perspective on the evolutionary history of Darwin's finches. Auk 119: 864-871.

ZinK, R. M., and R. C. Blackwell-Rago. 2000. Species limits and recent population history in the Curve-billed Thrasher. Condor 102:881-886.

Zink, R. M., AND M. C. McKitRick. 1995. The debate over species concepts and its implications for ornithology. Auk 112:701-719.

Associate Editor: R. C. Fleischer

APPENDIX.

\begin{tabular}{|c|c|c|c|c|}
\hline \multirow[b]{2}{*}{ Taxon } & \multirow[b]{2}{*}{ Catalogue numbera } & \multicolumn{2}{|c|}{ Accession numbers $^{b}$} & \multirow[b]{2}{*}{ Collection locality } \\
\hline & & $\mathrm{CR}$ & Cyt $b$ & \\
\hline I. spurius fuertesi (NVer-1) & MZFC 15595 & AY211221 & AY211206 & Mexico, northern Veracruz, Tecolutla \\
\hline I. spurius fuertesi (NVer-2) & MZFC 15534 & AY211222 & AY211207 & Mexico, northern Veracruz, Tecolutla \\
\hline I. spurius fuertesi (NVer-3) & MZFC 15533 & AY211223 & AY211208 & Mexico, northern Veracruz, Tecolutla \\
\hline I. spurius fuertesi (NVer-4) & MZFC 15532 & AY211224 & AY211209 & Mexico, northern Veracruz, Tecolutla \\
\hline I. spurius fuertesi (SVer-1) & MZFC 13565 & AY211218 & AY211214 & Mexico, southern Veracruz, Tlacotalpan \\
\hline I. spurius fuertesi (SVer-2) & BMNH 42538 & AY211219 & AY211215 & Mexico, southern Veracruz, Tlacotalpan \\
\hline I. spurius fuertesi (SVer-3) & MZFC 13568 & AY211220 & AY212245 & Mexico, southernVeracruz, Tlacotalpan \\
\hline I. spurius spurius $(\mathrm{CO})$ & LSUMZ B-3980 & AY211229 & - & USA, Colorado, Weld County \\
\hline I. spurius spurius (IL-1) & FMNH 383513 & AY211236 & AY211199 & USA, Illinois, Cook County \\
\hline I. spurius spurius (IL-2) & FMNH 383514 & AY211231 & - & USA, Illinois, Cook County \\
\hline I. spurius spurius (IL-3) & FMNH 389579 & AY211232 & - & USA, Illinois, Cook County \\
\hline I. spurius spurius (IL-4) & FMNH 384644 & AY211233 & - & USA, Illinois, Cook County \\
\hline I. spurius spurius (IL-5) & FMNH 390351 & AY211235 & - & USA, Illinois, DuPage County \\
\hline I. spurius spurius (IL-6) & FMNH 381975 & AY211234 & AY211197 & USA, Illinois, Cook County \\
\hline I. spurius spurius (KS) & UKNHM 91051 & AY211230 & AY211198 & USA, Kansas, Seward County \\
\hline I. spurius spurius (LA-1) & LSUMZ B-5929 & AY211236 & AY211199 & USA, Louisiana, Cameron Parish \\
\hline I. spurius spurius (LA-2) & LSUMZ B-6377 & AY211237 & - & USA, Louisiana, Cameron Parish \\
\hline I. spurius spurius (LA-3) & LSUMZ B-6378 & AY211238 & AY211200 & USA, Louisiana, Cameron Parish \\
\hline I. spurius spurius (LA-4) & LSUMZ B-6379 & AY211239 & AY211201 & USA, Louisiana, Cameron Parish \\
\hline I. spurius spurius (LA-5) & LSUMZ B-6380 & AY211240 & AY211202 & USA, Louisiana, Cameron Parish \\
\hline I. spurius spurius (LA-6) & LSUMZ B-6382 & AY211241 & AY211203 & USA, Louisiana, Cameron Parish \\
\hline I. spurius spurius (LA-7) & LSUMZ B-8464 & AY211242 & AY211204 & USA, Louisiana, Cameron Parish \\
\hline
\end{tabular}


APPENDIX. (Continued.)

\begin{tabular}{|c|c|c|c|c|}
\hline \multirow[b]{2}{*}{ Taxon } & \multirow[b]{2}{*}{ Catalogue number ${ }^{a}$} & \multicolumn{2}{|c|}{ Accession numbers ${ }^{b}$} & \multirow[b]{2}{*}{ Collection locality } \\
\hline & & $\mathrm{CR}$ & Cyt $b$ & \\
\hline I. spurius spurius $(\mathrm{NC})$ & NCSM 15229 & AY211243 & - & USA, North Carolina, Pender County \\
\hline I. spurius spurius (PA-1) & ANSP 10125 & AY211244 & AY211205 & USA, Pennsylvania, Bucks County \\
\hline I. spurius spurius (PA-2) & ANSP 10147 & AY211245 & AY211210 & USA, Pennsylvania, Bucks County \\
\hline I. spurius spurius (VA) & ANSP 10210 & AY211246 & AY211211 & USA, Virginia, Accomack County \\
\hline I. spurius spurius (Gua-1) & MZFC 5439 & AY211247 & - & Mexico, Guanajuato, Santiaguillo \\
\hline I. spurius spurius (Gua-2) & MZFC 5440 & AY211226 & - & Mexico, Guanajuato, Santiaguillo \\
\hline I. spurius spurius (Gua-3) & MZFC 5474 & AY211227 & - & $\begin{array}{l}\text { Mexico, Guanajuato, San Pedro } \\
\text { de los Naranjos }\end{array}$ \\
\hline I. spurius spurius (Gua-4) & MZFC 5454 & AY211225 & - & Mexico, Guanajuato, Santiago Maravatis \\
\hline I. prosthemelas (1) & MZFC 13573 & AY211228 & - & Mexico, Campeche, Xpujil \\
\hline I. prosthemelas (2) & BMNH 42543 & - & AY211212 & Mexico, Campeche, Xpujil \\
\hline I. prosthemelas (3) & BMNH 42542 & - & AF099289 & Mexico, Yucatan, Chichen Itza \\
\hline I. dominicensis (1) & MVZ 178920 & - & AY211213 & Dominican Republic, Samana \\
\hline I. dominicensis (2) & NKK 1112 & AY211216 & AY211195 & Dominican Republic, Peravia \\
\hline \multicolumn{5}{|c|}{$\begin{array}{l}\text { aMuseums are abbreviated as follows: ANSP = Academy of Natural Sciences, Philadelphia; BMNH = J. F. Bell Museum of Natural History, } \\
\text { University of Minnesota; FMNH = Field Museum of Natural History; LSUMZ = Louisiana State University Museum of Zoology; MVZ = Museum of } \\
\text { Vertebrate Zoology, University of California, Berkeley; MZFC = Museo de Zoología, Facultad de Ciencias, Universidad Nacional Autónoma de } \\
\text { México; NCSM = North Carolina State Museum; and UKNHM = University of Kansas Natural History Museum. (NKK } 1112 \text { was collected by Nedra } \\
\text { K. Klein } 8 \text { July 1998.) }\end{array}$} \\
\hline
\end{tabular}

